\title{
HTLV-I ASSOCIATED MYELOPATHY IN PORTO ALEGRE (SOUTHERN BRAZIL)
}

\author{
MÁRCIO MENNA-BARRETO;, ALEXANDRE DOVAL', GIORGIO RABOLINI', OTOMAR BIANCHINI' *
}

SUMMARY - HTLV-I associated myelopathy/tropical spastic paraparesis (TSP/HAM) have been increasingly described in practically all regions of Brazil. Five confirmed and documented cases of patients with TSP/HAM in Rio Grande do Sul are reported; in all of them spastic paraparesis, neurogenic bladder and superficial and/or profound sensitive disorders were observed in variable degrees. One patient presented a relapsing-remitting course with a cerebellar ataxia (multiple sclerosis-like pattern). Everyone was submitted to clinical, serological, urodynamic, neurophysiologic and neuroradiologic investigation. The aim of this study was to present the southem region of Brazil as an area with significant endemicity for HTLV-L/II infection (prevalence of $0.42 \%$ between blood donors), and also to show the existence of patients with neurologic disease associated with this retrovirus.

KEY WORDS: HTLV-I, myelopathy, tropical spastic paraparesis, neurogenic bladder, TSP/HAM, multiple sclerosis, Brazil.

\section{Mielopatia associada ao HTLV-I em Porto Alegre (Sul do Brasil)}

RESUMO - Mielopatia associada ao HTLV-L/paraparesia espástica tropical (TSP/HAM) tem sido đescrita de forma crescente em praticamente todas as regiōes do Brasil. Relatam-se cinco casos confirmados e documentados de pacientes com TSP/HAM no Rio Grande do Sul, observando-se em todos paraparesia espástica, bexiga neurogênica e distúrbios sensitivos superficiais e/ou profundos de graus variáveis. Em um caso denotou-se padrão em surto e remissão, caracterizado por ataxia cerebelar (sugestivo de esclerose múltipla). Os cinco pacientes foram submetidos a investigação clínica, laboratorial, urodinâmica, neurofisiológica e de neuroimagem. O objetivo do presente trabalho foi apresentar a região sul do Brasil como uma área de significativa endemicidade de infeç̧ão por HTLV-U/II (0,42\% de prevalência entre doadores de sangue), bem como evidenciar a existência de pacientes com doença neurologica associada a este retrovírus.

PALAVRAS-CHAVE: HTLV-I, mielopatia, paraparesia espástica tropical, bexiga neurogênica, PET/ MAH, esclerose múltipla, Brasil.

The T-cell lymphotropic virus type I (HTLV-I) was the first retrovirus to be isolated in human patients ${ }^{23}$. It belongs to the sub-family of oncoviridae type $\mathrm{C}$, and is at present classified within the BLV-HTLV group, which includes HTLV-I, HTLV-II, Simian T-Cell Leukemia Virus (STLV), and Bovine Leukemia Virus (BLV) ${ }^{1,16}$. HTLV-I is endemic to the southwest region of Japan, the Caribbean islands, sub-equatorial regions of Africa and Latin America ${ }^{3,6,8,14,20,14-27,34,35}$. One of the diseases caused by it is a chronic progressive myelopathy presenting as spasticity, weakness in the lower limbs, and sphincter dysfunctions, called tropical spastic paraparesis/HTLV-I associated myelopathy(TSP/HAM ${ }^{9,12,21.25 .27 .31}$. In Brazil it has been found mainly in the northeast and southeast regions ${ }^{2,4.7 .15,24.29,30}$. Recently, endemicity was also shown in the southern region of Brazil, in blood bank tests, and the first cases of myelopathy were confirmed ${ }^{18,19}$.

We describe some of the first confirmed and documented cases of TSP/HAM in the state of Rio Grande do Sul, including that one already presented ${ }^{19}$.

'Unidade de Neuroretrovirologia do HTLV (Clínica Virion) do Hospital Porto Alegre; "Laboratório Bianchini \& Jardim de Análises Clínicas. Aceite: 27-junho-1995. 


\section{METHODS}

During the period from June to December 1994, patients with non-traumatic and non-tumoral myelopathies seen at three general hospitals in Porto Alegre (Hospital Porto Alegre, Hospital Nossa Senhora da Conceição and Hospital Mãe de Deus) were investigated. They presented symptoms of progressive myelopathy with spastic paraparesis, neurogenic bladder and/or diminished sensitivity in the lower limbs ${ }^{9.27}$. Twelve patients were submitted to research on anti-HTLV-I/II antibodies using the particle agglutination method (Serodia, Fujirebio), and five of them were serum reactive. The results were confirmed by Western Blot (Cambridge Biotech, Worcester , U.S.A., or HTLV Blot, 2.3. Diagnostic Biotechnology, Singapore), with a standard for HTLV-I. ${ }^{5,33}$ (Fig 1). Then samples of CSF were obtained on which the same tests were performed, complemented by urodynamic assessment, neurophysiologic study (somato-sensory evoked potential) and neuroimaging (magnetic resonance, computed tomography or myelography). Disability was measure according to Kurtzke's expanded disability status scale (EDSS). All of them fulfilled the WHO diagnostic guidelines for HAM/TSP22.

\section{RESULTS}

The five patients with TSP/HAM (41.6\%) are aged from 29 to 69 years. Two were Caucasian, two mulatto and one black. Four patients were female, one of them the former wife of the single male. It should be stressed that she already presented a certain degree of spastic gait when she began her relationship.

Sexual transmission was dominant in four cases, and one case of coexisting use of injectable drugs also occurred. In one of the patients it was not possible to determine the factor of contagion.

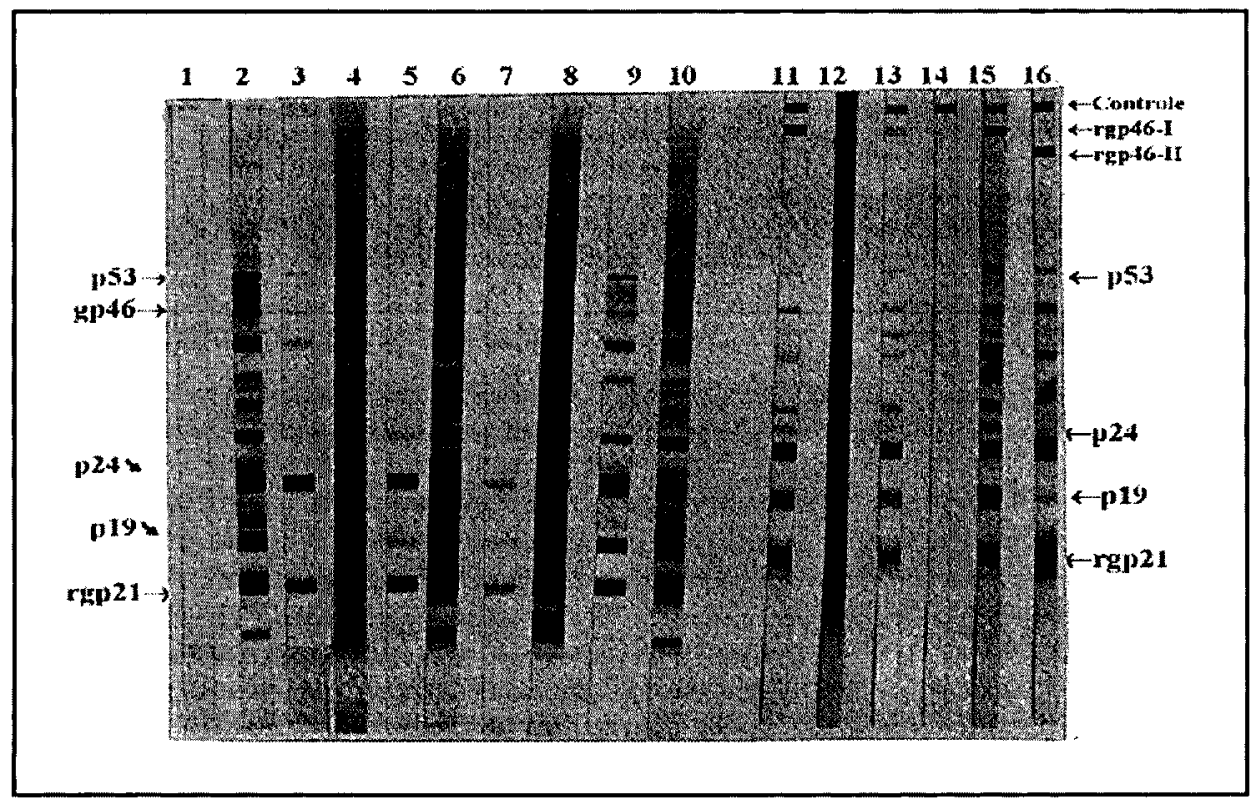

Fig 1. HTLV-I/II western blot. Lanes 1-10 = Western Blot Cambridge Biotech and lanes 11-16 reference Western Blot 2.3. Diagnostic Biotecnology. Lanes $J-3=$ to negative, positive HTLV-I and positive HTLV-II control; lanes 4-5 = serum and CSF samples from patient $A$; lanes $6-7=$ serum and CSF samples for patient $B$; lanes $8.9=$ serum and CSF samples from patient $C$; lanes 10-11 = serum and CSF samples from patient $D$; lanes $12-13=$ serum and CSF samples from patient $E$; lanes $14-16=$ refrence to negative, postive $H T L V-l$ and positive HTLV-II controls, respectively. 


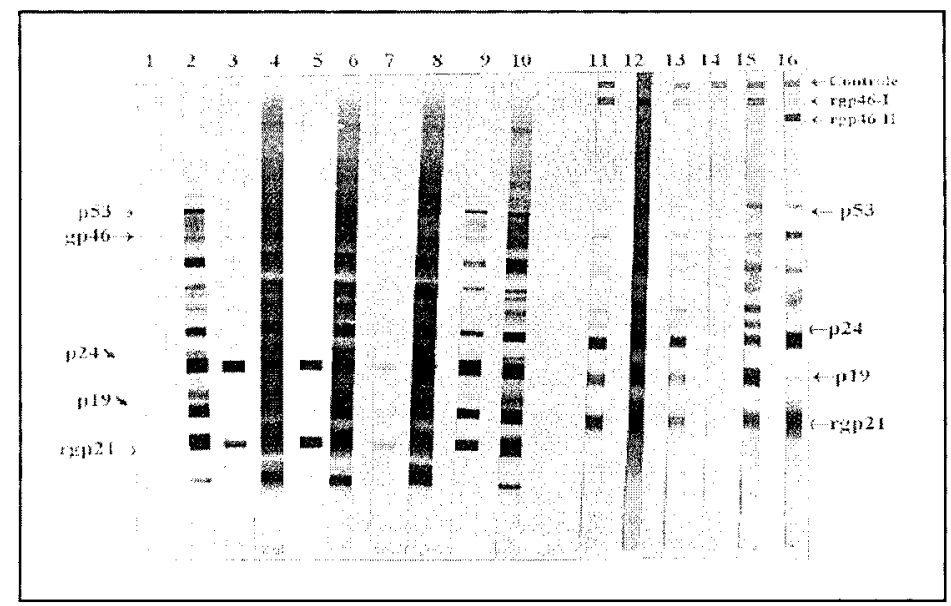

Fig 1. HTLV-IIII western blot. Lanes J-IO = Westem Blot Cambridge Biotech and lanes $11-16$ reference Western Blot 2.3. Diagnostic Biotecnology. Lanes $1-3=$ to negative, positive HTLV-I and positive HTLV-II comtrol; lanes 4-5 = serum and CSF samples from patient $A$; lanes 6-7 = serum and CSF samples for patient $B$; lanes $8-9=$ serum and CSF samples from patient $C$; lanes $10-11=$ serum and CSF samples from patient $D$; lanes $12-13=$ serum and CSF samples from patient $E$; lanes $14-16=$ refrence to negative, postive HTLV-I and positive HTLV-II controls, respectively. 
The time of evolution of the disease ranged from 5 months to 15 years. Three of them walked without help and two were already bedridden. The points on the EDSS ranged from 3 to 8, with a median of 5.9. Four patients had a typically chronic-progressive disease, though one female (patient "C"), with the shortest time of evolution, had presented a multiple sclerosis (MS)-like pattern with a spontaneous remission and an EDSS falling from 5 to grade 2, after an acute ataxia at the beginning; her husband and one of two daughters were also seropositive for HTLV-I.

The main clinical signs consisted of paraparesis or spastic paraplegia with signs of lesions of the pyramidal tract bilaterally affecting the lower limbs (increased tendinous reflexes, ankle clonus, extensor cutaneous plantar reflex and abolition of cutaneous-abdominal reflexes). Atrophy of the muscles of the lower limbs was found in four of the patients, excluding the one who had the shortest time of evolution. In all patients there was severe loss of vibratory sensitivity (hypopallesthesia) and bathyesthesia. The complaints of back pain, paresthesia and dysesthesia were not constant in the patients studied. Syphilis serology and research on anti-HIV antibodies were negative in the patients with TSP/HAM.

Test on CSF found moderate pleocytosis in one of the patients. Hyperproteinorrhachia was seen in three of them. In two cases a definite increase in gammaglobulin was noted. The CSF IgG was studied in four of the patients, and a rise was present in three. The Western blot for HTLV-I/II found antibodies against viral proteins of the gag, env and recombinant regions, indicating HTLV-I infection (Table).

The urinary symptoms included hesitancy, pollakiuria and urgency incontinence. The urodynamic assessments were typical of hyperreflexive bladders with detrusor-sphincterian dyssynergy and high vesical residues. All the patients had constipation and reduced libido; the male patient also presented erectile dysfunction.

In the neuroimaging study, three patients were submitted to magnetic resonance of the spinal canal, and a certain degree of atrophy at the thoracic level was found in the female patient who had had the disease longest. One of the patients underwent computed tomography and another conventional myelography, both of which did not show any visible changes.

In the study of somato-sensory evoked potential (SEPs), no changes were found in the upper limbs; however, there was a delay in the time of conduction through the lemniscal pathways to the lower limbs.

Table. CSF findings for the five patients with TSP/HAM.

\begin{tabular}{|c|c|c|c|c|c|}
\hline CASE & CELL & PROTEIN & GAMA GLOBULIN & $\operatorname{Ig} G$ & WESTERN BLOT \\
\hline A & 23 & 18 & $17 \%$ & 7 & $\begin{array}{l}\text { p21 p28 p42 p19 p32 } \\
\text { gp } 46 \text { p24 p38 p53 }\end{array}$ \\
\hline B & 4 & 86 & $15 \%$ & 4 & p21 p19 p24 p38 gp46 \\
\hline $\mathrm{C}$ & 1 & 83 & $28 \%$ & 7.9 & $\begin{array}{l}\text { gp } 46 \text { p53 p28 p38 } \\
\text { p19 p24 p21 }\end{array}$ \\
\hline D & 4 & 64 & $33 \%$ & - & $\begin{array}{l}\text { gp21 p19 rgp46-1 p24 } \\
\text { p53 p26 p32 p36 }\end{array}$ \\
\hline$E$ & 6 & 20 & $7.6 \%$ & 6.3 & $\begin{array}{l}\text { rgp } 46-1 \text { p53 gp } 46 \text { p26 } \\
\text { p32 p19 rgp21 p36 } \\
\text { p24 p28 }\end{array}$ \\
\hline
\end{tabular}




\section{COMMENTS}

TSP/HAM has been related mainly to certain ethnic groups, mainly black, yellow and NativeAmerican $^{2,17,20,34,35}$. In Brazil, the geographic distribution of these groups has favored documentation, in most cases, in the southeast and northeast regions. In the meta-analysis recently performed by Castro-Costa ${ }^{4}$, a gap is found due to the lack of reports on cases of TSP/HAM in some regions of Brazil (south, center, north).

Rio Grande do Sul (RS) is the southermost state of Brazil, presenting racial patterns compatible with the heavy European immigration (Italian and German), associated with Hispanic-Native American miscigenation due to the bordering countries (Uruguay and Argentina). The state capital is Porto Alegre, now with a population of approximately $1,300,000$, located at $30^{\circ}$ Lat. South and $51^{\circ}$ Long. West is the venue of this study ${ }^{10}$ (Fig 2). All the patients were born in and came from the capital of Rio Grande do Sul, and had already undergone previous investigation, except the one in whom the disease was of shortest standing. The predominant factor of contagion was sexual (heterosexual); there was no confirmation of transmission by blood or vertically. The time of evolution of the disease was not proportional to the greater degree of functional disability, since the male patient, who probably was infected two years ago by his partner and developed the myelopathy nine months ago, presented the highest degree of disability, attaining 8 points in the EDSS ${ }^{13}$. All the patients presented an initial asymmetric involvement in the lower limbs with ascending characteristics, and some of them already showed signs of pyramidal lesion in the upper limbs. The signs of progressive paraparesis, paraparetospastic gait and autonomic dysfunction (constipation and neurogenic bladder) predominated ${ }^{26}$. The sensitive symptoms were not constant and in some cases did not appear. Cerebellar involvement was the dominant feature in just one case. None of the patients presented co-infection with HIV or positive serology for syphilis.

The CSF exam was unspecific, and was used in the differential diagnosis for other diseases ${ }^{30}$. The neuroimaging exams to study the thoracolumbar spinal canal helped exclude compressive pathologies and, in one of the cases, suggested the existence of spinal cord atrophy ${ }^{31}$. The SEPs only showed involvement in the lower limbs of all patients".

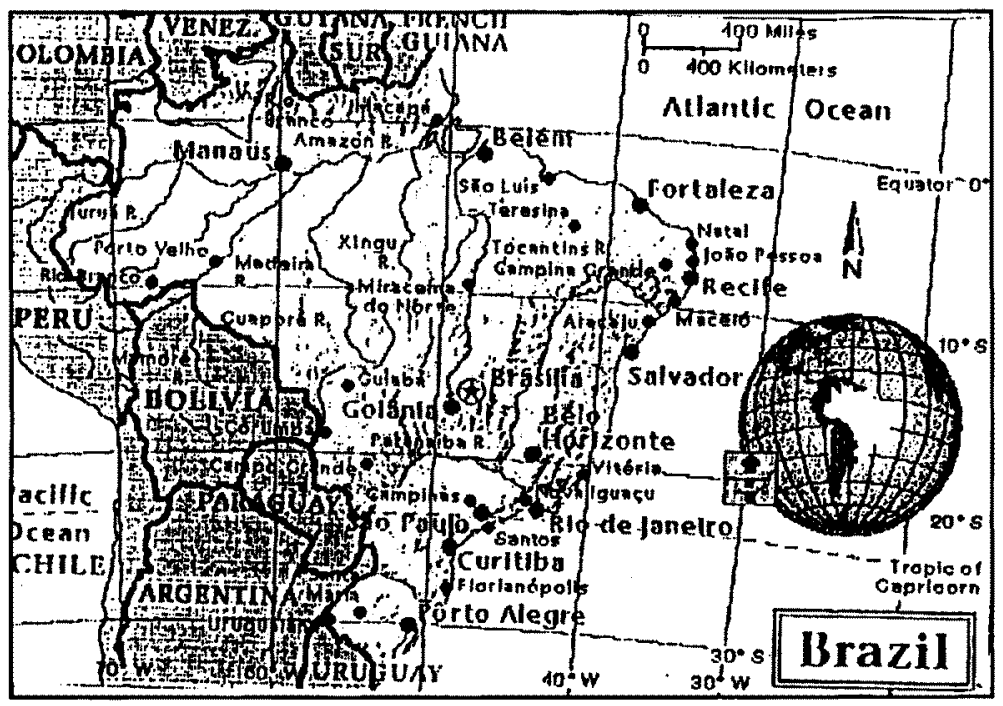

Fig 2. Porto Alegre, capital city of Rio Grande do Sul State, Brazil. 
The urodynamic investigation was performed in all patients, and a detrusor-sphincterian dyssynergy was found which had led to the complaint of dysuria; vesical hyperreflexiveness was correlated to pollakiuria and micturition urgency 28,32 .

The prevalence of 0.3 to $0.42 \%$ in blood donors, and also the description of cases of TSP/ HAM in Rio Grande do Sul lead to the assumption that the retroviruses HTLV-I and HTLV-II, besides being endemic are correlated to the significant percentages of indeterminate myelopathies, and it will be necessary to perform broader studies to gain a real understanding of the problem.

Addendum: After submission of this article, four out of five patients who are still alive had their peripheral blood mononuclear cells collected, DNA proviral extracted and amplified by a polymerase chain reaction (PCR), also confirming molecularly the diagnosis and typing of HTLV-I (Simbios Biotechnology-Porto Alegre).

Acknowledgements - We thank Dr. Jeanette Farina( Instituto de Neurofisiologia Clínica), Dr. Claudio Lima (Instituto de Urodinâmica), Dr. Breno Riegel Santos ( Medical Director of Hospital Nossa Senhora da Conceição), Dr. Mario Marques Henrique Filho (Medical Director of Hospital Porto Alegre), to employees of Laboratório Bianchini \& Jardim (Clinical Tests) and Dr. Abelardo Queiroz-Campos de Araújo for their kindness and encouragement.

\section{REFERENCES}

1. Andrada-Serpa MJ. Retroviridae. In Santos Oliveira LH. Virologia Humana. Rio de Janeiro: Ed Cultura Médica, 1994, p 315-338.

2. Araujo AQ-C, Afonso CR, Schor D, Leite AC, Andrada Serpa MJ. Clinical and demographic features of HTLV-I associated myelopathy/ tropical spastic paraparesis (HAM/TSP) in Rio de Janeiro, Brazil. Acta Neurol Scand 1993, 88:59-62.

3. Blank A, Yamaguchi K, Blattner W, Kiokawa H. Report of the fifth conference on human retrovirology: human T-cell lymphotropic virus. Jpn J Clin Oncol 1993, 23: 134-142.

4. Castro-Costa CM, Carton H, Goubau P. Brazilian studies on tropical spastic paraparesis. Arq Neuropsiquiatr 1994, 52:585-591.

5. CDC. Licensure of screening test for antibody to human T-lymphotropic virus type 1. MMWR 1988, 37: 736-747.

6. Del Pino N, Peralta LM, Pampuro S, Pimentel E, Libonatti O. HTLV-1/11: seroprevalence and coinfection with other pathogens in blood donors in Buenos Aires. J Acquir Immune Defic Syndr 1994, 7:206-207.

7. Gabbai AA, Bordin JO, Vieira-Filho JPB, Roman GC. Selectivity of human T lymphotropic virus type-1 (HTLV-1) and HTLV-2 infection among different populations in Brazil. Am J Trop Med Hyg 1993, 49:664-671.

8. Gessain A, Koralnik I, Fullen J, Boeri E, Mora C, Blank A, Salazar-Grueso E F, Kaplan J, Saxinger WC, Davidson M, Lairmore MD, Levine P, Franchini G. Phylogenetic study of ten new HTLV-I strains from the americas. AIDS Res Hum Retrov 1994, 10: 103-106.

9. Höllsberg $P$, Hafler DA. Pathogenesis of diseases induced by human lymphotropic virus type I infection. $N$ Engl J Med 1993, 328:1173-1182.

10. IBGE-Divisão de Pesquisa do Rio Grande do Sul. Estimativa de população, data base: 01/07/93. Diário Oficial da União 31/08/94, seção 1:13118-13120.

11. Kakigi R, Kuroda Y, Takashima H, Endo C, Neshige R, Shibasaki H. Physiological functions of the ascending spinal tracts in HTLV-I associated myelopathy(HAM). Electroenceph Clin Neurophysiol 1992, 84:110 -114.

12. Koprowski H, DeFreitas E. HTLV-I and chronic nervous diseases: present status and a look into the future. Ann Neurol 1988, 23 (Suppl): S 166-S 170.

13. Kurtzke JF. Rating neurology inpairment in multiple sclerosis: an expanded disability status scale (EDSS). Neurology 1983, 33:1444-1452.

14. Levine PH, Blattner WA, Clark J. Geographic distribution of HTLV-I and identification of new high-risk population. Int J Cancer 1988, 2: 7- 12.

15. Matutes E, Schuz T, Andrada Serpa M, Queiroz-Campos Araújo A, Pombo de Oliveira M. Report of the Second International Symposium on HTLV in Brazil. Leukemia 1994, 8:1092-1094.

16. McAlister A. El vírus HTLV-I: aspectos generales y biologia molecular. In Zaninovic V, Galindo J, Blank A. Enfermedades asociadas con el vírus HTLV-I. Cali, Colombia: Fundacion MAR, 1992, p 1-10.

17. Melo A, Gomes I, Mattos K. Mielopatias pelo HTLV-I na cidade de Salvador, Bahia. Arq Neuropsiquiatr $1994,52: 320-325$. 
18. Menna-Barreto M, Rabolini G, Doval A. Seropositividade de anticorpos anti-HTLV VII em doadores de sangue no Rio Grande do Sul. Boletim 1994, 16 (167): 310.

19. Menna-Barreto M, Rabolini G, Doval A. Mielopatia associada ao HTLV-I em Porto Alegre: enfoque multidisciplinar. Boletim 1994, 16 (167): 313.

20. Molgaard CA, Eisenman PA, Ryden LA, Golbeck AL. Neuro-epidemiology of human T-lymphotropic virus type 1- associated tropical spastic paraparesis. Neuroepidemiology 1989, 8:109-123.

21. Osame M, Matsumoto M, Usuku K, Izumo S, Ijichi N, Amitani H, Tara M, Igata A. Chronic progressive myelopathy associated with elevated antibodies to human T-lymphotropic virus type I and adult T-cell leukemialike cells. Ann Neurol 1987, 21:117-122.

22. Osame, M. Review of WHO Kagoshima meeting and diagnostic guidelines for HAM/TSP. In Blattner, WA.(ed.) Human retrovirology: HTLV. New York: Raven Press 1990, p 191-197.

23. Poiesz BJ, Ruscetti FW, Gazdar AF, Bunn PA, Minna JD, Gallo RC. Detection and isolation of type C retrovirus particles from fresh and culture lymphocytes of patients with cutaneous T-cell lymphoma. Proc Natl Acad Sci USA 1980, 77:7415-7419.

24. Pombo de Oliveira MS, Matutes E, Farmadas LC, Schulzs TF, Calabro ML, Nucci M, Andrada-Serpa MJ, Tedder RS, Weiss RA, Catovsky D. Adult T-cell leukemia/lymphoma in Brazil and its relation to HTLV-I. Lancet 1990, 336: 978-990.

25. Rodgers-Johnson P, Morgan O, Mora C, Sarin P, Ceroni M, Piccardo P, Garruto R, Gibbs C, Gajdusek D. The role of HTLV-I in tropical spastic paraparesis in Jamaica. Ann Neurol 1988, 23 (Suppl): S 121-S 126.

26. Roman GC. The neuroepidemiology of tropical spastic paraparesis. Ann Neurol 1988, 23 (Suppl): S 111-S 120.

27. Roman GC, Roman L, Spencer PS, Schoenberg BS. Tropical spastic paraparesis: a neuroepidemiological study in Colombia. Ann Neurol 1985, 17: 361-365.

28. Saito M, Kondo A, Kato K, Gotoh M. Bladder dysfunction due to human T-lymphotropic virus type I associated myelopathy. Br J Urol 1991, 68: 365-368.

29. Sereno A, Galvão B, Proietti F, Rodrigues L, Franco L, Santana A, Loures L. HTLV I/II differential geographic distribution in Brazil. In: Proceedings of the Tenth International Conference on AIDS [Abstract PCO603]. Yokoama, Japan. 7 to 11 August, 1994.

30. Spina-França A, Livramento JA, Machado LR, Gomes HR, Viana LS, Castro LHM, Nóbrega JPS. HTLVI antibodies in serum and cerebrospinal fluid in tropical spastic paraparesis in Brazil. Arq Neuropsiquiatr 1990, 48:441-447.

31. Vernant JC, Maurs L, Gessain A, Barin F, Gout O, Delaporte JM, Sanhadji K, Buisson G, de-Thé G. Endemic tropical spastic paraparesis associated with human T-lymphotropic virus type I: a clinical and seroepidemiological study of 25 cases. Ann Neurol 1987, 21: 123-130.

32. Walton G, Kaplan S. Urinary dysfunction in tropical spastic paraparesis: preliminary urodynamic survey. J Urol 1993, 150: 930-932.

33. Weiss SH. Laboratory detection of human retroviral infection.In Wormser GP (ed). AIDS and other manifestations of HIV infection. Ed 2. New York: Raven Press, 1992, p 95-116.

34. Yanagihara R. Geographic-specific genotypes or topotypes of human T-cell lymphotropic virus type 1 as markers for early and recent migrations of human populations. Adv Virus Res 1994, 4:147-186.

35. Zaninovic V, Sanzon F, Lopes F, Velandia G, Blank A, Blank M, Fujiyama C, Yashiki S, Matsumoto D, Katahira Y, Miyashita H, Fujiyoshi T, Chan L, Sawada T, Miura T, Hayami M, Tajima K, Sonoda S. Geographic independence of the HTLV-I and HTLV-II foci in the Andes Highland, the Atlantic Coast, and the Orinoco of Colombia. AIDS Res Hum Retrov 1994, 10:97-101. 